Saudi Journal of Pathology and Microbiology

Abbreviated Key Title: Saudi J Pathol Microbiol ISSN 2518-3362 (Print) |ISSN 2518-3370 (Online) Scholars Middle East Publishers, Dubai, United Arab Emirates

Journal homepage: http://scholarsmepub.com/sipm/

Case Report

\title{
Asbestosis Exposure, Not Always a Mesothelioma: A Case Report
}

Bourhroum N*, Chadi F, Tbouda M, Jahid A, Elouazzani H, Zouidia F, Znati K, Bernoussi Z, Mahassini N

Pathology Department of Ibn Sina Hospital, Rabat Morocco

Faculty of Medicine and Pharmacy Mohamed V University; Rabat Morocco

DOI: $10.36348 /$ SJPM.2019.v04i10.008

| Received: 20.10.2019 | Accepted: 27.10.2019 | Published: 30.10 .2019

*Corresponding author: N. Bourhroum

\section{Abstract}

How to respond to pleural thickening on a chest X-ray or CT? Benign pathology or potentially serious subclinical cancer? The differential diagnosis is wide. Only the pathological examination can decide.

Keywords: Pachypleuritis, Asbestos, Mesothelioma.

Copyright @ 2019: This is an open-access article distributed under the terms of the Creative Commons Attribution license which permits unrestricted use, distribution, and reproduction in any medium for non-commercial use (NonCommercial, or CC-BY-NC) provided the original author and sources are credited.

\section{INTRODUCTION}

If cancers are the main concern of the health consequences of exposure to asbestos, it is the nonmalignant diseases, largely dominated by pleural plaques, which are by far the most frequent affections due to exposures to this mineral.

\section{CASE REPORT}

We report the case of a 70-year-old woman who worked at the Moorish bath for 45 years, admitted for the management of acute chest pain with acute coronary syndrome.
The discovery of basal-thoracic pleural thickening with a syndrome of fluid effusion having motivated the realization of a CT scan which showed the presence of a non-parenchymal calcified pleural plaque (Figure1).

After inconclusive pleural biopsies, a parietectomy decision with pathological examination in favor of a calcified pachypleuritis without sign of malignancy showing on microscopic examination acellulaire hyaline fibrous tissue with broad calcifications foci (Figure2).
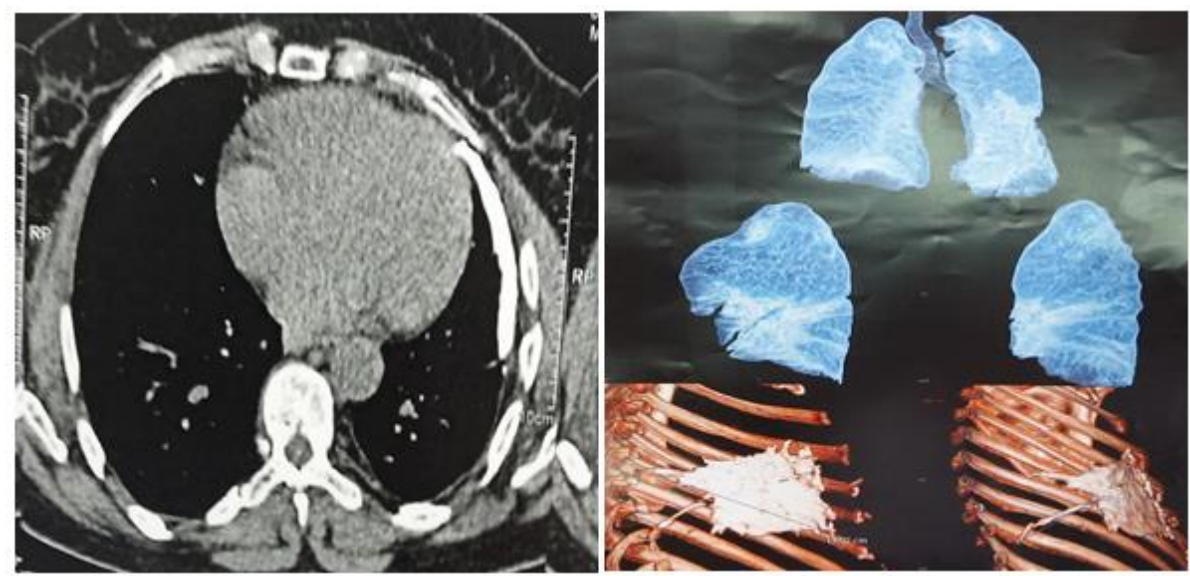

Fig-1: CT scan shows the presence of a non-parenchymal calcified pleural plaque 


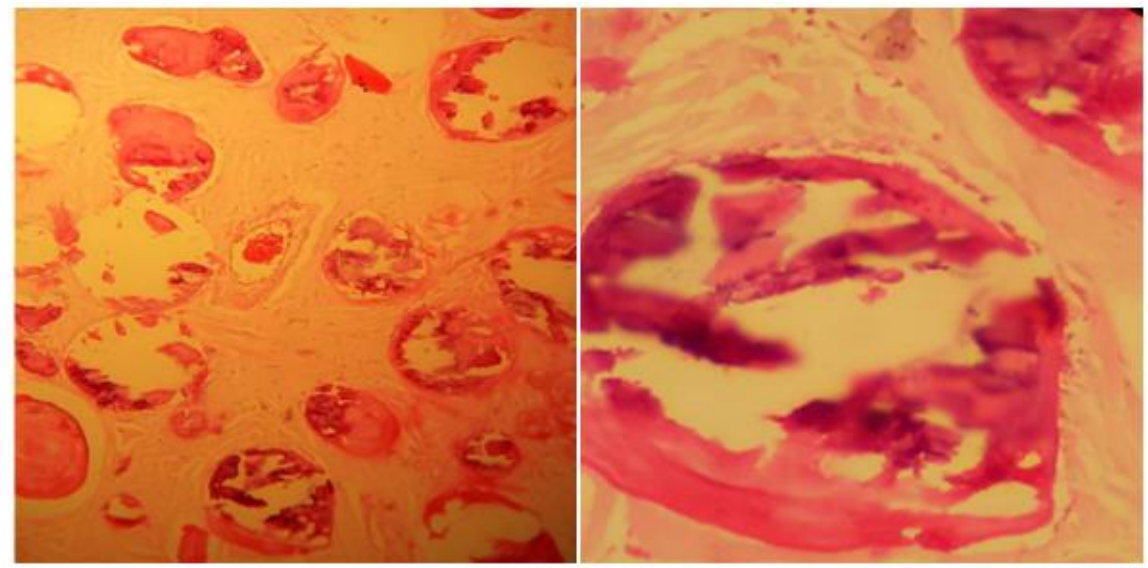

Fig-2: Acellulaire hyaline fibrous tissue with broad calcifications foci, Hematoxylin and eosin staining; A: HEx40 and B: HEx200

\section{DISCUSSION}

A fibrothorax usually is a consequence of severe inflammation of the pleura due to conditions like asbestos exposure, empyema, hemothorax, tuberculosis, connective tissue disease, uremia, drug reactions, or therapeutic pleurodesis [1].

Anamnesis, symptoms and physical examination are deeply the key elements that guide the diagnosis and treatement [2].

Pleural plaques are the most common abnormality encountered after 20 to 30 years of latency at asbestos exposure (58\% incidence), they increase with age and affect the men between 50 and 70 years [2]. Their pathogenesis is debated: the hypothesis put forward is a fiber deposit at the level of the parietal leaflet by retrograde intercostal lymphatic way, sparing the visceral pleura [2].
In case of exposure to asbestos, the radiography is supplemented by pulmonary functions and in case of radiological doubt, a complement by a CT is necessary to confirm the thickening and look for any parenchymal lesions [2].

\section{CONCLUSION}

This observation also confirms the diagnostic difficulties raised by minor pleural or pulmonary images, frequently identified during routine CT screening, and the need for precise diagnostic criteria, given the compensatory consequences attached to them.

\section{REFERENCES}

1. Alhassan, S., Fasanya, A., \& Thirumala, R. (2017). Extensive Calcified Fibrothorax. American journal of respiratory and critical care medicine, 195(4), e25-e26.

2. Schaer, B., \& Michel, Y. (2012). Pachypleurite: quand et comment investiguer? Revue médicale suisse, (355), 1826. 